\title{
Digestible Methionine + Cysteine-To-Lysine Ideal Ratio for Meat-Type Quails at Initial Phase
}

\section{-Author(s)}

\author{
Reis RSI \\ Viana GS" \\ Barreto SLT \\ Muniz JCL" \\ Mendonça $\mathrm{MO}^{\mathrm{II}}$ \\ Mencalha RIV \\ Ribeiro CLN" \\ Barbosa LMR"
}

Universidade Federal de São João del Rei, São João del Rei, Minas Gerais, Brasil

" Universidade Federal de Viçosa, Viçosa, Minas Gerais, Brasil

III Instituto Federal Sudeste de Minas, Rio Pomba, Minas Gerais, Brasil

Iv Universidade Federal de Lavras, Lavras, Minas Gerais, Brasil

\section{Mail Address}

Corresponding author e-mail address Renata de Souza Reis

Rua Tobias Rodrigues Mendonça Chaves, $n^{\circ}$ 67, Colônia do Marçal, São João del Rei, Minas Gerais, Brasil.

Email: renatareis@ufsj.edu.br

\section{neywords}

Coturnix coturnix coturnix, digestible amino acids, Sulphur amino acids.

\section{ABSTRACT}

This trial was performed to determine the ideal ratio of digestible methionine + cysteine (Met/Lys) with digestible lysine for meat-type quails from 1 to 14 days of age. A total of six hundred thirty, oneday-old, not sexed meat type quails were randomly assigned to six groups of treatments, each one with seven replicates and fifteen quails per experimental unit. A basal diet, methionine + cysteine-deficient, was graded supplemented with DL-Methionine (0.108; 0.169; 0.230; $0.291 ; 0.352$ and $0.413 \%$ ) to obtain the treatments, represented by six digestible Met/Lys ratios (0.60; 0.65; 0.70; 0.75; 0.80 and 0.85). Data was analyzed using ANOVA and polynomial regression and brokenline models were used to estimate the digestible Met/Lys ideal ratio, considering adjust of data to both models. Statistical significance was considered when $p \leq 0.05$. Feed intake, weight gain and final body weight was linearly increased as dig. Met/Lys ratio increased. Feeding conversion was improved with increasing in dig. Met/Lys ratios. A quadratic response on feathering percentage was observed with increasing dig. Met/Lys ratios. Digestible Met/Lys ratio which, maximized feathering percentage in meat-type quails, was 0.74. According to linear broken-line model, dig. Met/Lys ratio estimated for optimum feed intake, weight gain, final body weight and feeding conversion were, respectively, 0.66; 0.71; 0.71 and 0.74 . The dig. Met/Lys ideal ratio for meat-type quails from one to 14 days of age is 0.74 .

\section{INTRODUCTION}

Ideal protein concept has allowed reduction on crude protein content of poultry diets. Over the last decade studies have demonstrated that crystalline amino acid (e.g. lysine, methionine and threonine) supplementation on low-protein diets is an efficient method to enhance nitrogen retention by poultry and reduce costs without compromising bird performance. The application of ideal protein concept on poultry diet formulation mainly depends on the previously establishment of ideal ratios between amino acids with lysine on digestible basis. Data about ideal amino acid pattern for optimum broiler growth have been extensively studied, being already well established. However, researches reporting data about meat-type quail amino acid requirements are sparse and discrepant.

Tables for Japanese and European Quails (Silva \& Costa, 2009) describe nutritional requirements of both species. However, as described by the authors, the ideal amino acid pattern for meat-type quails is based on broiler amino acid requirements recommended by NRC (1994), which might not represent quail requirements. Among essential amino acids, methionine + cysteine are the first limiting amino acids in poultry diets, based on corn and soybean meal (Ravindran 
Reis RS, Viana GS, Barreto SLT,

Muniz JCL, Mendonça MO,

Mencalha R, Ribeiro CLN,

Barbosa LMR

\section{Digestible Methionine + Cysteine-To-Lysine Ideal \\ Ratio for Meat-Type Quails at Initial Phase}

\& Bryden, 1999). In addition to their essentiality for adequate poultry growth, Sulphur amino acids and methionine + cysteine are required to the formation of feathers and glutathione synthesis (Baker, 1991). As a methyl donor molecule, methionine also plays an essential role on creatine, polyamines, melatonin and phosphatidylcholine synthesis. Few reports about methionine + cysteine-to-lysine ideal ratio for meattype quails are available in literature. Scherer (2009) has estimated the dig. Met/Lys ideal ratio for meattype quails at initial phase in 0.84 , whereas Silva \& Costa (2009) has recommended a dig. Met/Lys ratio of 0.76 for quails in this phase. Considering few of the published data about dig. Met/Lys ideal ratio for meat-type quails at initial phase; but recognizing its importance, this trial was performed to determine the dig. Met/Lys ideal ratio for meat-type quails from 1 to 14 days of age.

\section{MATERIAL AND METHODS}

\section{Animal care and use}

All procedures adopted in this trial involving animal care and use, were previously approved by the institutional Animal Care and Use Committee of the Universidade Federal de Viçosa.

\section{Bird housing and management, experi- mental design and diets}

Six hundred thirty, one-day-old meat-type quails, obtained from local commercial hatchery, were randomly assigned to six groups of treatments with seven replicates and fifteen quails per experimental unit. The birds, not sexed, were housed in $50 \mathrm{mx}$ $50 \mathrm{~m} \times 30 \mathrm{~m}$ galvanized metal cages, placed above concrete countertops covered by shaving woods. All the cages were equipped with one nipple drinker and

Table 1 - Composition and nutrient content of experimental diets

\begin{tabular}{|c|c|c|c|c|c|c|}
\hline \multirow{2}{*}{ Ingredients } & \multicolumn{6}{|c|}{ Digestible methionine + cysteine-to-lysine ratios } \\
\hline & 0.60 & 0.65 & 0.70 & 0.75 & 0.80 & 0.85 \\
\hline Corn & 7.26 & 7.26 & 7.26 & 7.26 & 7.26 & 7.26 \\
\hline Soybean meal (45\%) & 45.07 & 45.07 & 45.07 & 45.07 & 45.07 & 45.07 \\
\hline Sorghum & 40.00 & 40.00 & 40.00 & 40.00 & 40.00 & 40.00 \\
\hline Soybean oil & 3.73 & 3.73 & 3.73 & 3.73 & 3.73 & 3.73 \\
\hline Limestone & 1.215 & 1.215 & 1.215 & 1.215 & 1.215 & 1.215 \\
\hline Dicalcium phosphate & 1.065 & 1.065 & 1.065 & 1.065 & 1.065 & 1.065 \\
\hline Salt & 0.382 & 0.382 & 0.382 & 0.382 & 0.382 & 0.382 \\
\hline Glutamic acid & 0.500 & 0.437 & 0.373 & 0.309 & 0.245 & 0.181 \\
\hline Corn starch & 0.100 & 0.102 & 0.105 & 0.108 & 0.111 & 0.114 \\
\hline L-Lysine HCI (79\%) & 0.000 & 0.000 & 0.000 & 0.000 & 0.000 & 0.000 \\
\hline DL-Methionine (99\%) & 0.108 & 0.169 & 0.230 & 0.291 & 0.352 & 0.413 \\
\hline L-Tryptophan (99\%) & 0.000 & 0.000 & 0.000 & 0.000 & 0.000 & 0.000 \\
\hline L-Arginine (99\%) & 0.131 & 0.131 & 0.131 & 0.131 & 0.131 & 0.131 \\
\hline L-Threonine (98\%) & 0.108 & 0.108 & 0.108 & 0.108 & 0.108 & 0.108 \\
\hline Choline chloride (60\%) & 0.100 & 0.100 & 0.100 & 0.100 & 0.100 & 0.100 \\
\hline Mineral premix & 0.070 & 0.070 & 0.070 & 0.070 & 0.070 & 0.070 \\
\hline Vitamin premix & 0.100 & 0.100 & 0.100 & 0.100 & 0.100 & 0.100 \\
\hline Antioxidant & 0.010 & 0.010 & 0.010 & 0.010 & 0.010 & 0.010 \\
\hline Antibiotic & 0.050 & 0.050 & 0.050 & 0.050 & 0.050 & 0.050 \\
\hline \multicolumn{7}{|l|}{ Calculated composition } \\
\hline Crude protein (\%) & 25.39 & 25.39 & 25.39 & 25.39 & 25.39 & 25.39 \\
\hline Metabolizable energy (kcal/kg) & 2903 & 2904 & 2905 & 2906 & 2907 & 2908 \\
\hline Calcium (\%) & 0.850 & 0.850 & 0.850 & 0.850 & 0.850 & 0.850 \\
\hline Non-phytate phosphorous (\%) & 0.320 & 0.320 & 0.320 & 0.320 & 0.320 & 0.320 \\
\hline Dig. Lysine (\%) & 1.23 & 1.23 & 1.23 & 1.23 & 1.23 & 1.23 \\
\hline Dig. Met + Cyst (\%) & 0.738 & 0.799 & 0.861 & 0.923 & 0.984 & 1.046 \\
\hline Dig. Threonine (\%) & 0.76 & 0.76 & 0.76 & 0.76 & 0.76 & 0.76 \\
\hline Dig. Tryptophan (\%) & 0.23 & 0.23 & 0.23 & 0.23 & 0.23 & 0.23 \\
\hline Dig. Arginine (\%) & 1.40 & 1.40 & 1.40 & 1.40 & 1.40 & 1.40 \\
\hline
\end{tabular}

${ }^{1}$ Composition/kg of product: Manganese 160g. Iron 100g. Zinc 100g. Copper 20g. Cobalt: 2g. lodine: $2 \mathrm{~g}$. Inert: $616 \mathrm{~g}$. ${ }^{2}$ Composition/kg of product: Vit. A:12.000.000 U.I.. Vit D3:3.600.000 U.I.. Vit. E: 3.500 U.I.. Vit B1:2.500 mg. Vit B2: 8.000 mg. Vit B6:5.000 mg. Pantothenic acid: 12.000 mg. Biotin: 200 mg. Vit. K:3.000 mg. Folic acid: 1.500mg. Nicotinic acid: $40.000 \mathrm{mg}$. Vit. B12: $20.000 \mathrm{mg}$. Selenium: $150 \mathrm{mg}$. Inert.. ${ }^{3}$ Butil-hidroxy-toluen. ${ }^{4}$ Avilamicin. ${ }^{5}$ Salinomicin $60 \%$. 
Reis RS, Viana GS, Barreto SLT, Muniz JCL, Mendonça MO, Mencalha R, Ribeiro CLN,

Barbosa LMR
Digestible Methionine + Cysteine-To-Lysine Ideal Ratio for Meat-Type Quails at Initial Phase one metal feeder. Experimental treatments consisted of six dig. Met/Lys ratios (0.60;0.65; $0.70 ; 0.75 ; 0.80$ and 0.85 ) obtained from the graded supplementation of DL-Methionine (0.108; 0.169; 0.230; $0.291 ; 0.352$ and $0.413 \%$ ) in a basal diet deficient in methionine + cysteine. Basal diet was formulated to meet or exceed Silva \& Costa (2009) recommendations. To formulate diets, a nutritional composition of ingredients described by Rostagno et al. (2011) was considered. Minimum and maximum temperature as well as air humidity were daily measured by thermo-hygrometers birds-height placed inside the experimental facility. Experimental diets (mash form) and water were provided ad libitum during the trial and light was supplied 24 hours a day (natural + artificial).

\section{Performance measurements}

At 14 days of age, the quails and feeders from all experimental units were weighed to determine final body weight and feed intake. Weight gain was obtained from the difference between average final body weight and initial body weight, considering the days the trial lasted (14 days). Feed conversion was calculated through the division of feed intake by weight gain. Mortality was recorded to adjust feed intake and feed conversion rate. After weighing birds and feeders, feeding was withdrawn for 4 hours to determine bird weight after fasting period. Then, 3 birds were stunned by electronarcosis and slaughtered by bleeding in jugular vein. Feathers were removed and weighed to obtain feathering percentage, which was calculated by dividing feather weight by bird weight after fasting.

\section{Statistical analysis}

The effects of dietary dig. Met/lys ratios were analyzed using ANOVA and optimal dig. Metl/Lys ratio was estimated using both polynomial and broken-line regression. Significant effect was considered when $p \leq 0.05$. The software package used to analyze data was Sistema de Análises Estatísticas e Genéticas (SAEG, 2007).

\section{RESULTS AND DISCUSSION}

Feed intake increased $(p<0.05)$ linearly as dig. Met/ Lys ratios increased (Table 2). Based on linear brokenline model estimative, dig. Met/Lys, which optimize quail feed intake, was 0.66 (Table 3). Castro (2014) reported linear increase in meat-type quail feed intake with increasing dig. Met/Lys ratios from 1 to 7 days of age. From 8 to 14 days of age, the same authors estimated the ratio of 0.70 as ideal for optimum quail feed intake.

Table 2 - Feed intake (FI), weight gain (WG), final body weight (FBW), feed conversion rate (FCR) and feathering percentage (FP) of meat-type quails from 1 to 14 days of age fed digestible Met/Lys ratios

\begin{tabular}{lccccc}
\hline Met + Cys-to-Lys ratio & $\mathrm{Fl}(\mathrm{g})$ & $\mathrm{WG}(\mathrm{g})$ & $\mathrm{FCR}(\mathrm{kg} / \mathrm{kg})$ & $\mathrm{BW}(\mathrm{g})$ & $\mathrm{FP}(\%)$ \\
60 & 129.18 & 72.31 & 1.79 & 82.7 & 6.07 \\
65 & 132.55 & 76.61 & 1.74 & 86.88 & 6.26 \\
70 & 135.86 & 81.03 & 1.68 & 91.25 & 6.39 \\
75 & 130.10 & 80.55 & 1.62 & 90.45 & 6.59 \\
80 & 133.25 & 82.38 & 1.62 & 92.58 & 6.57 \\
85 & 135.50 & 82.75 & 1.64 & 92.73 & 6.13 \\
CV1 (\%) & 6.36 & 6.97 & 4.15 & 6.30 & 7.55 \\
P-Value & & & & & \\
Linear & 0.303 & $<0.01$ & $<0.01$ & $<0.01$ & 1.00 \\
Quadratic & 0.999 & 0.126 & 0.015 & 0.145 & 0.03 \\
Linear Broken-Line & 0.025 & $<0.01$ & $<0.01$ & $<0.01$ & $<0.01$ \\
\hline
\end{tabular}

1 - Coefficient of variation.

Increasing dig. Met/Lys ratios led to linear $(p \leq 0,05)$ increase in quail weight gain and final body weight (Table 2), which, according to linear broken-line model estimates, were both optimized by the ratio of 0.71 (Table 3). Likewise, Castro (2014) observed a linear increase in meat-type quail weight gain from 1 to 7 days of age after ranging dig. Met/Lys ratios from 0.61 to 0.81 . The author, however, estimated the dig. Met/ Lys ratio for optimum meat-type quail growth from 8 to 14 days of age in 0.73 , considering the intersection between broken-line and quadratic curve. In contrast with our results, Scherer (2009) determined 0.84 and 0.81 as dig. Met/Lys ratio for optimum quail weight gain and final body weight at initial phase. Feeding conversion improved $(p<0.05)$ linearly in response to increasing in dig. Met/Lys ratios (Table 2). Linear brokenline regression was used to estimate the optimum quail feeding conversion, which was observed with the dig. Met/Lys ratio of 0.74 (Table 3). Such results are in agreement with those reported by Dozier \&

Table 3 - Linear broken-line and quadratic regression equations for feed intake (FI), weight gain (WG), final body weight (FBW), feed conversion rate (FCR) and feathering percentage of meat-type quails from 1 to $14 \mathrm{~d}$ of age.

\begin{tabular}{lcccc} 
Variable & $\begin{array}{c}\text { Linear broken-line regression } \\
\text { equations }\end{array}$ & $\mathrm{R}^{2}$ & Plateau & Met/Lys ratio \\
\hline FI & $89.1099+66.80001$ Met/Lys & 0.98 & 132.95 & 0.66 \\
\hline WG & $19.970+87.20$ Met/Lys & 0.99 & 81.79 & 0.71 \\
\hline FBW & $31.3016+85.5001$ Met/Lys & 0.99 & 91.92 & 0.71 \\
\hline FCR & $2.4870-1.160$ Met/Lys & 0.98 & 1.629 & 0.74 \\
\hline Variable & Quadratic regression equation & $\mathrm{R}^{2}$ & & Met/Lys ratio \\
\hline FP & $-8.14136+39.6564 M_{\text {Met/Lys }-}$ & 0.81 & & 0.74 \\
\hline
\end{tabular}


Reis RS, Viana GS, Barreto SLT,

Muniz JCL, Mendonça MO,

Mencalha R, Ribeiro CLN,

Barbosa LMR

\section{Digestible Methionine + Cysteine-To-Lysine Ideal Ratio for Meat-Type Quails at Initial Phase}

Mercier (2013) who estimated dig. Met/Lys ratio for optimum 1 to 14 days old broiler feeding conversion in 0.74. Castro (2014) pointed out, respectively, 0.67 and 0.69 as dig. Met/Lys ratios for optimum meat-type quail feeding conversion from 1 to 7 days and 8 to 14 days of age. In contrast, Scherer (2009) estimated 0.89 as dig. Met/Lys ideal ratio for meat-type quail feeding conversion from 1 to 14 days of age.

Based on performance results obtained in this current trial, ideal dig. Met/Lys ratio for meat-type quails from 1 to14 days of age is 0.74 . Such results indicate a narrow difference between our findings and Silva \& Costa (2009) recommendations, which describe 0.76 as ideal dig. Met/Lys ratio for meat-type quails at initial phase. Similarly, Rostagno et al. (2011) recommends dig. Met/Lys ratio of 0.72 for broilers at initial phase.

Beyond serving as blocks for body protein synthesis, amino acids play important secondary functions, which also contribute for adequate poultry growth. Methionine, which is not incorporated into protein, is the starting material for the biosynthesis of numerous other biochemical molecules. Methylation of acceptors molecules by S-adenosylmethionine, into methioninehomocysteine pathway, is a critical step in the synthesis of many proteins, including creatine in liver (Miller, 2003). Zhan et al. (2006) observed that concentration of creatine increased in broilers liver ${ }_{L}$ in response to methionine supplementation.

After its synthesis in liver, creatine is released into the circulation from where it can be taken up by tissues (Edison et al., 2007), including muscular tissue. Creatine is the precursor of creatine phosphate, which represents two roles in muscle function: it carries high-energy phosphate from mitochondria to myosin filaments; and it acts as a reservoir of highenergy phosphate that can regenerate ATP from ADP (Lieberman \& Marks, 1996). Thus, considering the high demand for energy in birds at initial phase, caused by the rapid growth rates, increasing creatine concentration in muscle could enhance poultry growth. Once methionine participates on creatine synthesis, it is expected that it leads to the increase in muscular creatine concentrations. Such hypothesis could explain the positive effects of increasing dig. Met/Lys ratios on weight gain and final body weight observed in this current trial.

Sulphur amino acids are essential to the formation of feathers. Cysteine is synthetized from methionine in a vitamin B6-dependent pathway. The condensation of two molecules of cysteine form one molecule of cysteine, which compose approximately $7 \%$ of feather amino acids pattern (Gous et al., 1999). In this trial, feathering percentage showed a quadratic response $(p<0.05)$ to dig. Met/Lys ratios, being optimized by the ratio of 0.74 . Feathering data were also significant $(p<0.05)$ according to broken-line regression. However, considering the higher coefficient of determination $\left(R^{2}\right)$ for quadratic regression, which indicates a better fit of the model, dig. Met/Lys ratio for optimum feathering percentage was estimated using quadratic regression. In contrast, Scherer (2009) did not observe effects of dig. Met/Lys ratios on meat-quails feathering from 1 to 14 days of age. Based on results, the digestible Met/ Lys ideal ratio for meat-type quails from 1 to 14 days of age is 0.74 .

\section{REFERENCES}

Baker DH. Partitioning of nutrients for growth and other metabolic functions. Poultry Science1991;(70)8:1797-1805.

Castro MR. Relações metionina + cistina: lisina digestíveis para codornas de corte [dissertation]. Diamantina (MG): Universidade Federal do vale do Jequitinhonha e Mucuri; 2014.

Dozier WA, MERCIER, Y. Ratio of digestible total sulfur amino acids to lysine of broiler chicks from 1 to 15 days of age. The Journal of Applied Poultry Research 2013;(22)4:862-887.

Edison EE, Brosnan ME, Meyer C, Brosnan JT. Creatine synthesis: production of guanidinoacetate by the rat and human kidney in vivo.American Journal of Physiology Renal Physiology 2007;(293)6:1799-1804.

Gous RM, Moran ET, Stilborn HR, Bradford GD, Emmans GC. Evaluation of the parameters needed to describe the overall growth, the chemical growth, and the growth of feathers and breast muscles of broilers. Poultry Science 1999;(78)6:812-821.

Lieberman M, Marks AD. Mark's basic medical biochemistry. $4^{\text {th }}$ ed Baltimore: Williams \& Wilkins; 1996.

Miller AL. The methionine-homocysteine cycle and its effects on cognitive diseases. Alternative Medicine Review2003;(8)1:7-19.

NRC - National Research Council. Nutrient requirements of poultry. $9^{\text {th }}$ ed Washington: National Academy Press; 1994.

Ravindran V, Bryden WL. Amino acid availability in poultry-In vitro and in vivo measurements. Crop and Pasture Science 1999;(50)5:889-908.

Rostagno HS, Albino LFT, Donzele JL, Gomes PC, Oliveira RF, Lopes DC, et al. Tabelas brasileiras para aves e suínos: composição de alimentos e exigências nutricionais. 3rd ed. Viçosa: Universidade Federal de Viçosa; 2011.

Scherer C. Exigência de energia metabolizável, lisina e metionina + cistina digestíveis para codornas de corte em fase de crescimento [thesis]. Maringá (PR): Universidade Estadual de Maringá; 2009. 110 p.

Silva JHV, Costa FGP. Tabelas para codornas japonesas e Europeias: tópicos especiais, composição de alimentos e exigências nutricionais. 2nd ed. Jaboticabal: FUNEP; 2009

UFV - Universidade Federal de Viçosa. Sistema de analises estatísticas e genéticas - SAEG. Versão 8.0. Viçosa: UFV; 2000.

Zhan XA, Li JX, Xu ZR, Zhao RQ. Effects of methionine and betaine supplementation on growth performance, carcass composition and metabolism of lipids in male broilers. British Poultry Science 2006;47(5):576-580. 